\title{
BAGAIMANA PENANGANAN ARSIP DI BAGIAN TATA USAHA KANTOR PUSAT PENDIDIKAN DAN PELATIHAN KEMENTERIAN RISET, TEKNOLOGI DAN PENDIDIKAN TINGGI
}

Oleh: Dra. Ratna Suminar, MM. \& Endang Palupi

Ratnasuminar2255@gmail.com

\begin{abstract}
Abstrak
Arsip merupakan kumpulan warkat yang disimpan secara teratur dan terencana, karena memiliki nilai suatu kegunaan agar setiap kali diperlukan dapat ditemukan kembali. Jadi sebagai intinya arsip adalah himpunan lembaran-lembaran tulisan yang merupakan salah satu bukti/aset organisasi dan individu dalam mempertahankan hak dan kewenangan terhadap sesuatu yang menjadi hak milik.

Keberadaan arsip bagi organisasi/perusahaan dapat dijadikan sebagai tulang punggung manajemen organisasi, sedangkan bagi individu/masyarakat keberadaan arsip dapat juga menjadi simbol jati diri seseorang.

Untuk mempermudah mendapatkan arsip, dalam penyimpanannya menggunakan kode-kode khusus dan dikembangkan oleh masing-masing yang berkepentingan. Pengarsipan juga dikelompokkan sesuai kepentingan dan waktu kebergunaan/keterpakaian.

Pemberian kode/identitas kelompok arsip yang kurang jelas bahkan tidak ada, akan mendatangkan permasalahan dalam mendapatkan arsip yang dikehendaki dalam waktu relative singkat.

Peminjaman/pengeluaran arsip dari tempatnya tanpa dicatat, akan mendatangkan kesulitan untuk mengembalikan/mendapatkan/menempatkan kembali arsip-arsip tersebut.
\end{abstract}

Kata kunci: Penanganan arsip dapat mempertahankan hak, kewenangan dan kepemilikan.

\section{PENDAHULUAN}

\section{Latar Belakang masalah}

Dalam era globalisasi saat ini, informasi telah menjadi komoditi yang sangat berpengaruh terhadap perkembangan masyarakat. Informasi telah menjadi bagian yang tidak bisa terpisahkan dalam kehidupan berbangsa dan bernegara termasuk dalam wilayah hukum Negara Kesatuan Republik Indonesia. Dalam ruang lingkup yang kecil, informasi juga berpengaruh dalam kegiatan bisnis di kehidupan sosial masyarakat. Tanpa disadari keadaan ini 
berpengaruh juga pada perkembangan pengelolaan arsip sebagai salah satu sumber informasi premier dalam kehidupan organisasi maupun individual.

Berbicara mengenai arsip atau kearsipan maka seakan-akan yang terlihat masalah ini adalah masalah kecil yang juga sering dianggap sepele, sehingga banyak yang beranggapan tidak ada pengaruhnya terhadap kebijakan/proses administrasi sehari-hari di tiap instansi baik pemerintahan ataupun swasta, tetapi setelah ada insidenarsip/dokumen yang sulit untuk ditemukan atau hilang dan tidak diketahui bagaimana cara menemukannya kembali, maka setelah itu seluruh pimpinan/para manajer baru akan tersadar bahwa kearsipan atau arsip merupakan kunci/urat nadi dari instansi yang dipimpinnya dan sangat perlu diperhatikan sesuai dengan perkembangannya dimasa sekarang maupun dimasa yang akan datang.

Maka dari itu,perluadanyakesadaran dan perhatian yang lebihdarimasyarakat danatau organisasi/perusahaan terhadap pengelolaan arsip. Karenaarsipmerupakan salah satu bukti/aset organisasi dan individu yang harus dilindungi keberadaannya. Keberadaan arsip sebagai aset/kunci/urat nadi organisasi dan individu adalah sebagai bukti untuk mempertahankan hak dan kewenangan terhadap sesuatu yang sangat berharga yang menjadi hak milik. Keberadaan arsip bagi organisasi/perusahaan dapat dijadikan sebagai tulang punggung manajemen organisasi, sedangkan bagi individu/masyarkat keberadaan arsip dapat juga menjadi simbol jati diri yang bersangkutan.

Oleh karena itu, keberadaan arsip baik dalam lingkungan organisasi atau individu/masyarakat dapat memberikan manfaat bagi pengelolanya atau pemiliknya, dalam rangka meningkatkan pengetahuan dan keterampilan masyarakat dan terutama para pengelola arsip maka difokuskan kepada bagaimana Pengelolaan Arsip/Kearsipan sejalan dengan peraturan dan perundang-undangan Nomor 43 Tahun 2009 dalam bidang kearsipan yang mengatur tentang bagaimana arsip harus dikelola agar dapat berdayaguna baik bagi organisasinya maupun "stake holder-nya" sebagai pengguna arsip tersebut.

Tulisan ini disusun secara komprehensif dan sistematis untuk memberikan pengenalan pada kebijakan kearsipan yang berlaku saat ini dimulai dengan pengenalan konsep arsip secara umum. Pendekatan ini menjelaskan tentang pengertian arsip, perbedaannya dengan sumber informasi lain, karakteristik, serta fungsi dan nilai guna arsip. Pokok pembahasan lain memaparkan tentang pengelolaan arsip baik arsip dinamis maupun arsip statis. Pengelolaan arsip dinamis diantaranya mengenai pengertian, penciptaan arsip, pemeliharaan arsip dan penggunaan arsip serta penyusutan arsip. Sedangkan pengelolaan arsip statis diantaranya yaitu arsip yang dihasilkan oleh pencipta arsip karena memiliki nilaiguna kesejarahan, telah habis 
retensinya, dan berketerangan dipermanenkan yang telah diverifikasi baik secara langsung maupun tidak langsung oleh Arsip Nasional Republik Indonesia dan/atau lembaga kearsipan. Bahasan mengenai sejarah dan organisasi kerasipan juga dibahas dalam bagian terakhhir dari penulisan ini.

\section{Rumusan Masalah}

Berdasarkan latar belakang yang telah diuraikan diatas, maka penulis merumuskan sebagai berikut:

"Bagaimana Penanganan Arsip di Bagian Tata Usaha Kantor Pusat Pendidikan dan Pelatihan Kementerian Riset, Teknologi dan Pendidikan Tinggi”

\section{TINJAUAN PUSTAKA}

\section{Pengertian Arsip}

Menurut Modul Pengantar Kearsipan Pusat Pendidikan dan Pelatihan Kearsipan, Arsip Nasional Republik Indonesia (2015), hal.3:

"Secara etimologi kata arsip berasal dari bahasa Yunani (Archeion) dan bahasa Latin (archivum) yang berarti kantor pemerintah atau kertas yang disimpan di kantor pemerintah". Semula pengertian arsip itu menunjukan tempat atau gedung tempat penyimpanan arsipnya, tetapi perkembangan terakhir orang lebih cenderung menyebut arsip sebagai warkat itu sendiri. Shollenberg menggunakan istilah archives itu sebagai suatu kumpulan warkat itu sendiri dan archives instution sebagai gedung arsip atau lembaga kearsipan.

Setelah kita mengetahui kata arsip menurut etimologi, maka sebagai perbandingan dapat kita pelajari pula pengertian Arsip dari beberapa sumber.

Menurut Wursanto, 1998:14 Arsip dalam bahasa Belanda (Archief) adalah:

1. Tempat penyimpanan secara teratur, bahan-bahan arsip, bahan-bahan tertulis, piagampiagam, surat-surat, keputusan-keputusan, akte-akte, dokumen dan peta

2. Sebuah kumpulan yang teratur dari pada bahan-bahan kearsipan tersebut.

3. Bahan-bahan yang harus diarsip itu sendiri.

Menurut Peraturan Pemerintah Republik Indonesia Tahun 1979:

1. Arsip merupakan kumpulan naskah atau dokumen yang disiapkan.

2. Arsip merupakan gedung (ruang) penyimpanan kumpulan naskaah atau dokumen.

3. Arsip merupakan organisasi atau lembaga yang mengelola dan menyimpan kumpulan naskah atau dokumen. 
Menurut Lembaga Administrasi Negara (LAN) arsip adalah segala kertas, berkas, naskah, foto, film, mikro film, rekaman suara, gambar peta, bagan atau dokumen lain dalam segala macam bentuk dan sifatnya, atau salinan serta dengan segala cara penciptaannya dan yang dihasilkan atau diterima oleh suatu badan sebagai bukti dari tujuan organisasi, fungsifungsi kebijakan. Kebijakan-kebijakan, keputusan-keputusan, prosedur-prosedur, pekerjaanpekerjaan atau kegiatan-kegiatan lain pemerintah atau karena pentingnya informasi yang terkandung di dalamnya.

Menurut Drs. Lian Gie, arsip merupakan kumpulan warkat yang disimpan secara teratur dan terencana, karena memiliki nilai suatu kegunaan agar setiap kali diperlukan dapat ditemukan kembali. Jadi sebagai intinya arsip adalah himpunan lembaran-lembaran tulisan. Catatan tertulis yang disebut warkat harus memiliki 3 syarat, yaitu:

1. Disimpan secara berencana dan teratur

2. Mempunyai suatu kegunaan, dan

3. Dapat ditemukan kembali dengan cepat

Menurut kamus administrasi perkantoran (Wursanto, 1998;22) memberikan rumusan sebagai berikut;

"Sistem penyimpanan warkat atau (filling system) adalah rangkaian tatacara dan langkahlangkah yang harus dilaksanakan dalam menyimpan warkat-warkat, sehingga bilamana diperlukan lagi warkat-warkat itu dapat ditemukan kembali secara cepat”.

Pengertian lain menyebutkanbahwa filling atau pengarsipan adalah suatu system, metode, atau cara yang telah direncanakan dan dipergunakan dalam kepengurusan arsip (penyimpanan, pemeliharaan), sehingga arsip-arsip itu dapat ditemukan kembali dengan mudah dan cepat apabila sewaktu-waktudi perlukan. (Wursanto, 1991:22)

System kearsipan yang baik menurut Wursono (1998:30-32), disebutkan sebagai berikut:

1. Mudah Dilaksanakan

2. Mudah Dimengerti

3. Murah/Ekonomis

4. Tidakmakantempat

5. Mudahdicapai

6. Cocokbagiorganisasi

7. Fleksibel atau luwes

8. Dapat mencegah kerusakan atau kehilangan arsip

9. Mempermudah proses kearsipan 
Menurut Undang-Undang Nomor 7 Tahun 1971 arsip adalah naskah-naskah yang dibuat dan diterima oleh lembaga-lembaga dan badan-badan pemerintahan dalam bentuk apapun, baik dalam keadaan tunggal maupun berkelompok dalam rangka pelaksanaan, penyelenggaranaan kehidupan kebangsaan pada umumnya atau dipergunakan secara langsung dalam penyelenggaraan administrasi negara.

System kearsipan dapat dimengerti sebagai suatu kesatuan dari beberapa unsur yang terdiri dari input, proses, output, dan tujuan yang diperlukan untuk melakukan pengurusan warkat atau arsip dalam rangka mencapai tujuan kearsipan. Dan system kearsipan dapat digambarkan sebagai berikut:

Sistem Kearsipan

\section{SistemKearsipan}

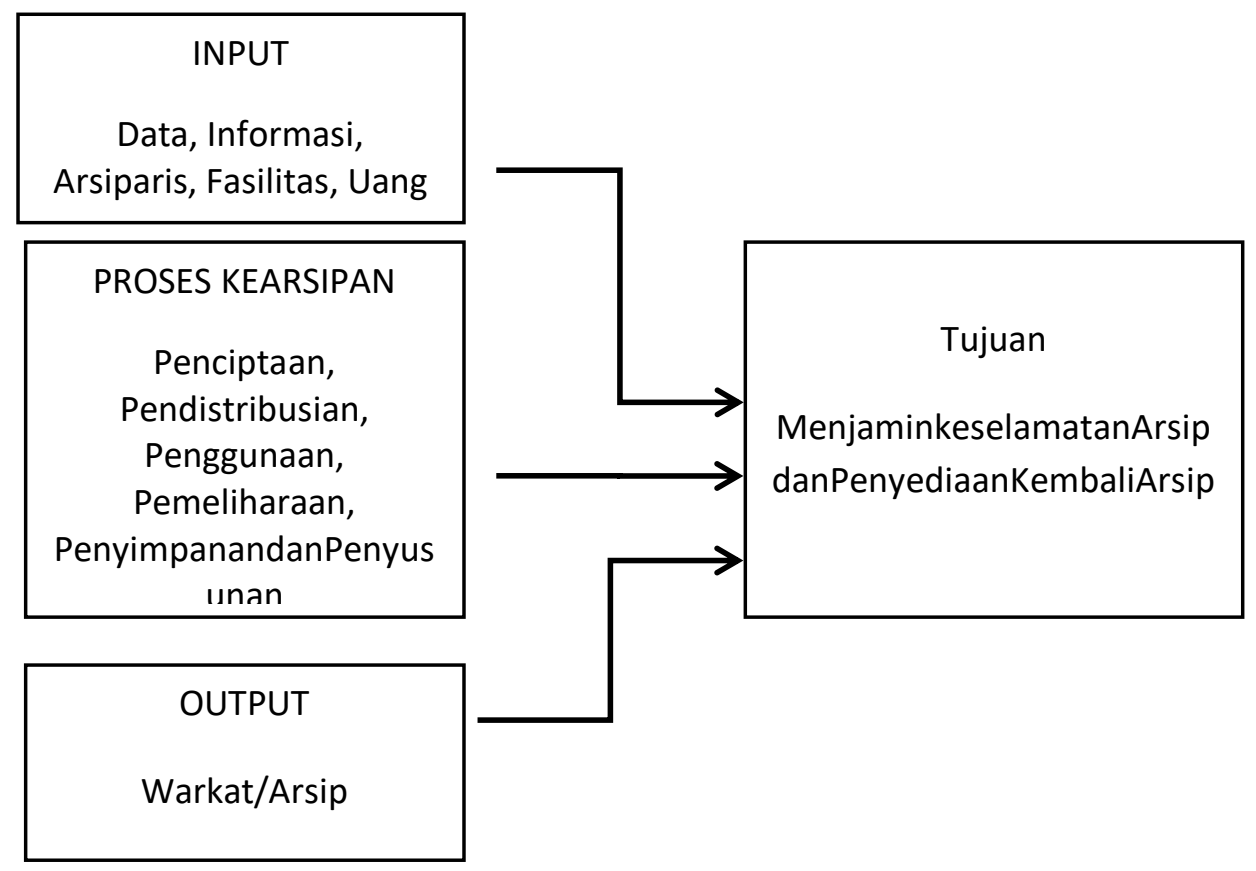

Dari beberapa pendapat diatas dapat ditarik kesimpulan bahwa system kearsipan adalah suatu metode atau cara yang telah direncanakan dalam pengurusan arsip, sehingga arsip-arsip dapat ditemukan kembali dengan mudah dan cepat apabilas ewaktu-waktu diperlukan. Adapun metode atau cara tersebut adalah meliputi tahap penerimaan, pencatatat, penyimpanan, penggunaan, pemeliharaan, penyusutan dan pemusnahan benda-benda arsip yang sering disebut dengan daur hidup arsip. 
Maka dalam system filling tidak hanya memperhatikan sistemnya saja tetapi juga pengelolaannya (manajemen) yang baik dan tepat, karena apabila manajemennya lemah, maka system yang telah ditentukan itu tidak akan ada artinya.

\section{Fungsi Arsip}

Fungsi Arsip dibedakan:

1. Arsip Dinamis yang dipergunakan secara langsung dalam perencanaan, pelaksanaan, penyelenggaraan kehidupan kebangsaan pada umumnya atau dipergunakan secara langsung dalam penyelenggaraan administrasi negara.

2. Arsip Statis yang tidak dipergunakan secara langsung untuk perencanaan, penyelenggaraan kehidupan kebangsaan pada umumnya maupun untuk penyelenggaraan sehari-hari administrasi negara.

Arsip merupakan sesuatu yang hidup, tumbuh dan terus berubah seirama dengan tata kehidupan masyarakat maupun dengan tata pemerintahan.

Ketentuan fungsi arsip tersebut menegaskan adanya dua jenis sifat dan arti arsip secara fungsional, yaitu:

1. Arsip Dinamis

Adalah sebagai arsip yang senantiasa masih berubah nilai dan artinya menurutkan fungsinya, dan

2. Arsip Statis

Adalah sebagai arsip yang sudah mencapai taraf nilai yang abadi khusus dan sebagai bahan pertanggungjawaban nasional atau pemerintahan.

Perlu sekali adanya ditentukan secara tegas mengenai cara-cara penilaian arsip menurut fungsinya ini, baik mengenai penentuan nilai dan arti menurut usia atau jangka waktu dan ataupun menurut evaluasi daya gunanya. Cara-cara penilaian tersebut akan diatur lebih lanjut dalam peraturan perundang-undangan. Perbedaan fungsi ini menjadi dasar dalam pelaksanaan tugas dan penugasan oleh pemerintah.

\section{Sistem Penyimpanan Arsip}

Sistem penyimpanan adalah sistem yang dipergunakan pada penyimpanan warkat agar memiliki kemudahan kerja peny9impanan dapat diciptakan dan penemuan warkat yang sudah disimpan dapat dilakukan dengan cepat bilama sewaktu-waktu warkta tersebut diperlukan. 
Sistem penyimpanan pada prinsipnya adalah menimpan berdasarkan kata tangkap (caption) dari warkat yang disimpan, baik yang berupa huruf maupun angka yang disusun menurut urutan tertentu. Pada umumnya sistem penyimpanan yang dapat dipakai sebagai sistem penyimpanan yang standar dapat dibedakan menjadi 5 macam, yaitu:

\section{Sistem Abjad (Alphabetical Filling System)}

Sistem Abjad adalah sistem penyimpanan arsip dengan memakai metode penyususnan menurut abjad. Umumnya dipakai untuk arsip yang dasar penyusunannya dilakukan terhadap nama orang, nama perusahaan atau organisasi, nama tempat, nama benda dan subjek masalah. Nama-nama diambil dari nama pengirim (surat masuk) dan nama alamat yang dituju (surat keluar). Cara menemukan dan menentukan tanda dari suatu dokumen yang akan dijadikan petunjuk atau tanda pengenal (caption) untuk memudahkan mengetahui tempat dokumen yang disimpan. Adapun kata tangkap dapat berupa: nama orang, nama perusahaan, nama tempat atau daerah, nama benda, istiloah subjek atau angka (tergantung sistem pengarsipan yang dipakai). Menentukan ciri atau tanda dengan cara menemukan urutan unit-unit atau bagian dari kata tangkap yang akan disusun menurut abjad.

Indeks adalah sarana untuk menemukan kembali dengan cara mengidentifikasi surat tersebut melalu penunjukan suatu tanda pengenal yang dapat membedakan surat yang satu dengan surat yang lainnya, atau bagian dari suatu nama yang dijadikan tanda pengenal surat. Unit dalah bagian kata dari kata tangkap yang memiliki pengertian sendiri, atau bagian terkecil dari suatu nama. Sedangkan namka, merupakan judul atau caption. Jadi setiap judul memiliki bagian yang disebut unit. Kode adalah suatu tanda atau simbol yang diberikan atau yang dibutuhkan pada lembaran arsip yang dapat dipakai untuk tanda penyimpanan arsip. Koding adalah suatu kegiatan memberikan tanda atau simbol pada arsip. Adapun fungsi dari kode atau simbol adalah menunjukan isi yang terkandung di dalam arsip yang bersangkutan. Petunjuk silang adalah alat petunjuk dari indeks yang tidak dipakai kepada indeks yang dipakai, atai petunjuk hubungan antar indeks yang dipakai dengan indeks lain yang dipakai.

\section{Sistem Perihal (Pokok Isi Surat)}

Sistem perihal adalah cara penyimpanan dan penemuan kembali surat berpedoman pada perihal surat atau pokok isi surat. Yang perlu dipersiapkan untuk sistem perihal adalah : 
a. daftar indeks : adalah daftar yang memuat seluruh kegiatan, masalah atau hal-hal yang dilakukan diseluruh kantor, dimana sistem ini diterapkan. Masalah-masalah tersebut kemudian diuraikan laagi. Masalah-masalah pokok tersebut dalam pembagian pembantu, apabila uraian masalah masih dibagi lagi menjadi masalah yang lebih kecil, disebut sub pembagian pembantu.

b. Perlengkapan menyimpan surat: Filling Cabinet, Guide, Folder, Kartu kendali

c. Pemberian kode surat

d. Penyimpanan surat dengan cara, membaca surat untuk mengetahui isi surat, memberi kode surat, mencatat surat dalam kartu kendali.

e. Menyimpan kartu kendali.

\section{Sistem Nomor}

Didalam sistem nomor ada 4 macam:

a. Sistem nomor menurut Dewey (Sistem Desimal atau Klasifikasi).

Sistem ini menetapkan kode surat berdasarkan nomor yang ditetapkan untuk surat yang bersangkutan.

b. Sistem nomor Terminal Digit

Didalam sistem ini kode penyimpanan dan dalam kode penemuan kembali surat memakai sistem penyimpanan menurut terminal digit, yaitu sistem penyimpanan berdasarkan pada nomor urut dalam buku arsip.

c. Sistem nomor Middle Digit

Sistem ini merupakan kombinasi dari sistem nomor Decimal Dewey dan sistem nomor Terminal Digit. Yang dijadikan kode laci dan guide adalah dua angka yang berada ditengahm sedangkan dua angka yang berada didepannya menunjuksn kode map, kemudian dua angka yang berada dibelakangnya menunjukan urutan surat yang kesekian didalam map. Dalam sistem ini kode angka harus berjumlah enam, sehingga terdapat dua angka ditengah, dua angka di depan dan dua angka dibelakang. Seandainya angka kode kurang dari enam maka harus ditambahkan angka nol didepannya sampai berjumlah enam angka.

d. Sistem nomor Soundx (phonetic sistem)

Sistem ini merupaka sistem penyimpanan warkat berdasarkan pengelompokan nama dan tulisannya atau bunyi pengucapannya hampir bersamaan. Dalam sistem ini nama- 
nama digaanti dengan kode (notasi) yang terdiri dari 1 huruf dan 3 angka. Susunan penyimpanannya adalah menurut abjad yang diikuti urutan nomor.

\section{Sistem Subjek (subjek filling sistem)}

Menjadikan kode penyimpanan dan penemuan kembali surat-surat ialah pokok isi atau masalah. Dalam penyelenggaraan sistem perihal (pokok masalah) ini maka petugas kearsipan harus menentukan terlebih dahulu hal-hal apa yang pada umumnya dipermasalahkan dengan surat yang bersangkutan. Misalnya, subjek "Kepegawaian", "Keuangan", dan yang lainnya.

a. Merancang klasifikasi masalah

b. Menyiapkan jenis perlengkapan, seperti:

1) Filling Cabinet

2) Guide

3) Map (Folder)

4) Rak Penyortir

5) Kartu Indeks

6) c. Menyimpan dan penemuan kembali arsip

7) Sistem Wilayah (Geographic Filling Sistem)

Sistem wilayah adalah sistem kearsipan yang diselenggarakan berdasarkan daerah atau wilayah surat yang diterima. Pada penyimpanan sistem wilayah, pembagian wilayah merupakan dasar pentapan kode yang akan menjadi dasar penyimpanan arsip. Untuk surat-surat masuk, maka nama wilayah dari asal surat tersebut menjadi dasar pengelompokan surat, sedangkan untuk surat keluar maka nama wilayah tujuan surat tersebut yang digunakan.

Sebagaimana sistem penyimpanan yang lain, untuk sistem wilayah juga menggunakan daftar klasifikasi, yaitu daftar klasifikasi wilayah. Untuk membuat daftar klasifikasi wilayah, pengetahuan tentang nama wilayah, di suatu kota, provinsi, kabupaten bahkan negara sangatlah diperlukan.

Daftar klasifikasi wilayah memuat pengelompokan wilayah menjadi wilayah utama, sub wilayah dan sub-sub wilayah. Wilayah-wilayah disusun berurutan sesuai dengan urutan abjad. Daftar klasifikasi wilayah dapat dibuat melalui beberapa macam, antara lain sebagai berikut:

1. Menurut Nama Negara, yaitu daftar klasifikasi wilayah yang dibuat berdasarkan pengelompokan wilayah berdasarkan nama negara. 
Contoh:

- Asia (wilayah utama)

- Asia Tenggara (sub wilayah)

- Brunei (sub-sub wilayah)

- Indonesia

- Malaysia

2. Menurut Pembagian Wilayah Administrasi Negara, yaitu daftar klasifikasi berdasarkanj pengelompokan nama wilayah administrasi suatu negara. Berikut adalah contoh daftar klasifikasi menurut pembagian wilayah administrasi negara.

- Jawa Barat (Provinsi)

- Bandung (kota/kab)

- Arjasari (Kecamatan)

- Baleendah

- Banjaran

3. Menurut wilayah administrasi khusus, yaitu daftarv klasifikasi yang dibuat berdasarkan pengelompokan wilayah administrasi yang khusus untuk kepentingan suatu badan/instansi tertentu. Berikut daftar klasifikasi menurut pembagian wilayah administrasi khusus untuk kepentingan suatu badan/instansi tertentu.

Wilayah 1

Kalimantan
Wilayah 2

Magelang

Didalam suatu kantor dapat saja diterapkan pemakaian satu sistem penyimpanan untuk semua file yang ada di kantor tersebut. Akan tetapi tidak jarang pula kantor yang menggunakan beberapa sistem penyimpanan untuk menghindari kesalahan dalam memilih arsip yang disimpan. Adapun prosedur penyimpanan arsip antara lain:

a. Memeriksa

Surat atau dokumen lainnya disimpen dan diperiksa apakah dokumen yang bersangkutan memang sudah layak disimpan atau masih dalam pemprosesan. Tanda siap disimpan, biasa disebut juga dengan istilah relasemark baik dalam bentuk stampel, paraf atau tanda file lainnya yang perlu diteliti oleh petugas. Pemeriksaan ini penting karena jika suatu saat terjadi petugas yang tidak teliti dalam memeriksa dan menyimpan surat yang seharusnya diteruskan atau didistribusikan kepada unit lain untuk diproses, maka terjadilah apa yang disebut dengan surat "Hilang". Sehingga akan menimbulkan 
kekacauan antar petugas yang saling menyalahkan satu sama lain pada saat ditanyakan dan dimintai pertanggungjawabannya.

b. Mengindeks

Mengindeks adalah proses menentukan kata tangkap (caption) dari suatu surat atau dokumen untuk kepentingan penyimpanan. Di dalam sebuah pekerjaan diharapkan petugas dapat menentukan subjek surat tidak hanya berdasarkan subjek yang tertulis pada perihal surat. Dari indeks ini, petugas dapat meelihat daftar klasifikasi subjek untuk mengetahui istilah yang bersangkutan secara lebih rinci.

c. Mengkode

Mengkode adalah memberi tanda pada surat dengan cara menuliskan kata-kata diatas kertas surat yang bersangkutan dengan tulisan tersebut, petugas dapat menyortir ataupun menempatkan surat sesuai dengan subjek yang benar. Atau berdasarkan kode tersebut petugas dapat menempatkan surat yang dikembalikan dari pinjaman ke tempatnya tanpa harus mengalami kesulitan karena kode penyimpanannya sudah ada.

d. Menyortir

Menyortir adalah mengelompokan surat terlebih dahulu untuk memudahkan pekerjaan penempatannya ditempat penyimpanan. Dengan adanya penyortiran, surat-surat disimpan bergiliran sesuai dengan kelompok demi kelompok. Jika surat yang akan disimpan hanya sedikit, maka tidak perlu disortir terlebih dahulu, karena dapat dilakukan penyimpanan sekaligus secara mudah.

f. Menempatkan

Dalam sisstem subjek pengelompokan arsip atau dokumen berdasarkan subjek atau pokok masalah. Perlengkapan yang dipergunakan yaitu map, laci, lemari arsip, ordner, rak arsip dan yang lainnya. Sarana penyimpanan arsip berupa istilah subjek. Istilah tersebut dimulai dari kelas utama, kelas sub-kelas, sub-sub kelas, tergantung jumlah surat dari subjek bersangkutan yang disimpan dengan pengelompokan yang lebih terperinci.

\section{Kantor}

Kantor dapat dibangun hampir di lokasi manapun dan dalam bangunan apapun, tetapi sejumlah persyaratan modern untuk perkantoran membuat hal ini lebih pelik. Persyaratan- 
persyaratan ini dapat berlandaskan hukum (misalnya, tingkat penerangan harus memadai) atau teknis (misalnya, persyaratan untuk network komputer). Di samping itu, persyaratan lain seperti keamanan dan fleksibilitas tataruang (layout), mengakibatkan pembuatan bangunan-bangunan khusus yang hanya atau terutama dikhususkan untuk perkantoran. Suatu "gedung perkantoran" (office building, juga disebut office block atau "business center" merupakan suatu bentuk bangunan komersial dengan ruang-ruang yang khusus didesain untuk perkantoran. Banyak gedung kantor juga mempunyai fasilitas dapur dan kamar staf, di mana para pekerja dapat makan atau beristirahat sejenak. Banyak ruang kantor sekarang juga merupakan ruang serviced office, yang berarti para penghuninya dapat berbagi ruangan dan fasilitas.

\section{Pengertian Tata Usaha}

Tata usaha merupakan kata majemuk yang arti umumnya ialah kegiatan dalam kantor. Ditinjau dari aktifitas pokoknya, tata usaha adalah kegiatan untuk mengadakan pencatatan dan penyusunan keterangan-keterangan sehingga keterangan-keterangan itu dapat dipergunakan secara langsung sebagai bahan informasi bagi pimpinan organisasi atau perusahaan yang bersangkutan atau dapat dipergunakan siapa saja yang dibutuhkannya.

Menurut (Saiman, 2002; 15) tata artinya suatu aturan/peraturan yang harus ditaati sedangkan usaha berarti suatu kegiatan dengan mengarahkan tenaga pikiran/badan untuk mencapai suatu tujuan. Maka dapat disimpulkan tata usaha ialah suatu peraturan yang terdapat dalam suatu proses penyelenggaraan kerja

Menurut Waworuntu dalam (Saiman 1991; 15) Administrasi merupakan proses penyelenggaraan organisasi secara menyeluruh, sedangkan tata usaha sebagai kegiatan pencatatan, penggolongan data dan tulis menulis dari proses tersebut.

Tata usaha sifatnya membantu atau menunjang bagi kelancaran pekerjaan pokok perkantoran/organisasi, sehingga tata usaha merupakan unsur administrasi dalam suatu kantor/organisasi. Sehingga merupakan keseluruhan proses kerjasama antara dua orang/lebih yang didasarkan atas rasionalitas tertentu mencapai tujuan yang telah disepakati bersama, maka kegiatan tata usaha amat diperlukan dalam suatu kantor.

Pekerjaan tata usaha selalu berhubungan dengan pekerjaan-pekerjaan lainnya dalam sebuah organisasi. Tata usaha membantu memperlancar semua pekerjaan pada sebuah kantor, dengan menyediakan arsip-arsip penting yang dibutuhkan oleh suatu bagian dalam melaksanakan pekerjaannya. Agar tata usaha dapat berjalan dengan baik dan maksimal, maka 
diperlukan suatu sistem tata usaha yang baik, dimana urutan pekerjaan tata usahs harus disusun dan dijalankan dengan teratur.

\section{Kegiatan Tata Usaha}

Menurut Waworuntu dalam Saiman $(1991 ; 17)$ kegiatan tata usaha merupakan kegiatan yang berhubungan dengan jasa - jasa perkantoran yang terdiri dari hal-hal berikut ini:

1. Korespondensi dan lapangan kegiatan ini berhubungan dengan pencatatan relasi atau kemitraan kerja organisasi ataupun kantor sampai pada persiapan hal-hal yang harus dilaporkan kepada pimpinan.

2. Tata hubungan yang berhubungan dengan proses surat menyurat, penerimaan dan pengiriman telepon serta faximile.

3. Pencatatan dan perhitungan, kegiatan ini berhubungan dengan data-data laporan, data statistik, dan lain-lain.

4. Kearsipan, hal ini penting dalam rangka penyimpanan surat-surat atau dokumen yang dinilai penting dan berkaitan dengan kegiatan kantor/organisasi

Tata usaha terdapat dalam setiap organisasi pada tingkat pimpinan tertinggi sampai lapisan yang terbawah. Selanjutnya di antara satuan-satuan organisasi setiap badan usaha, baik teratas bahkan sebaliknya maupun dari samping ke sisi lainnya serta silang-menyilang dari dan kemanapun, tentu terjadi hubungan kerja yang dapat disebut hubungan tata usaha. Hubungan tata usaha ialah kontak di antara segenap satuan organisasi satu sama lain yang tidak menyangkut perintah dan tanya jawab melainkan penyampaian keterangan-keterangan dalam rangka memberikan pelayanan kepada pelaksanaan pekerjaan-pekerjaan yang operatif.

Hubungan-hubungan tata usaha umumnya itu terwujud dalam bentuk syarat, formulir, salinan, kutipan, tembusan atau sesuatu macam warkat lainnya baik instansi pemerintah maupun perusahaan swasta dengan baik dan perseorangan dan masing-masing.

Penyelenggaraan kegiatan pencatatan-pencatatan yang cermat adalah memelihara dokumen yang penting sekali untuk keterangan dan bahan-bahan ingatan dalam menyusun program bagian kantor tersebut. Administrasi kearsipan pada bagian umum meliputi kegiatan yaitu melaksanakan penerimaan surat, pencatatan surat dan pendistribusian surat.

Menurut Waworuntu dalam (Saiman, 1991; 18) dari peranan tata usaha tersebut, maka tata usaha merupakan proses penyelenggaraan yang berwujud 6 (enam) pola, yaitu sebagai berikut: 
1. Menghimpun yaitu kegiatan-kegiatan mengusahakan tersedianya segala keterangan yang tadinya belum ada atau berserakan di mana-mana sehingga siap untuk dipergunakan bilamana diperlukan.

2. Mencatat yaitu kegiatan membubuhkan dengan berbagai peralatan tulis keteranganketerangan yang diperlukan sehingga terwujud tulisan yang dapat dibaca, dikirim dan disimpan. Dalam perkembangan teknologi modern sekarang ini termasuk pula memakai keterangan-keterangan itu dengan alat-alat perekam suara sehingga dapat didengar, misalnya "pencatatan" pada pita rekaman.

3. Mengolah yaitu bermacam-macam kegiatan mengerjakan keterangan-keterangan dengan maksud menjalankannya dalam bentuk yang lebih berguna.

4. Mengganda yaitu kegiatan memperbanyak dengan berbagai cara dan alat sebanyak jumlah yang diperlukan.

5. Mengirim yaitu kegiatan menyampaikan dengan berbagai cara dan alat dari satu pihak ke pihak lainnya.

6. Menyimpan yaitu kegiatan menaruh dengan berbagai cara dan alat di tempat tertentu yang aman.

\section{Ciri Ciri Pelaksanaan Tata Usaha}

Dalam pelaksanaan tata usaha mempunyai ciri-ciri tersendiri, ciri-ciri tersebut adalah:

1. Bersifat Pelayanan

Dalam hal ini tata usaha hanyalah memberi pelayanan dan bantuan agar satuan operatif dapat menghasilkan keuntungan atau tujuan yang akan dicapai.

2. Bersifat Merembes Kesegenap Bagian Dalam Organisasi

Ini berarti tata usaha sangat diperlukan di mana-mana dan dilaksanakan dalam seluruh organisasi. Lebih dari itu Tata Usaha dapat mencapai ke segala tempat dan tidak hanya terbatas dalam lingkungan bangunan, gedung, tata kantor dari suatu badan usaha atau organisasi yang bersangkutan.

3. Dilaksanakan Oleh Semua Pihak Dalam Organisasi

Tata usaha dilaksanakan oleh semua pihak yang ada dalam organisasi terlepas dari tugasnya masing-masing. Walaupun Tata Usaha merupakan tugas dari sekelompok pegawai tapi juga dapat dilakukan oleh pejabat pimpinan yang tertinggi dan tidak mengubah kedudukan pejabat tersebut sebagai kepala yang tugas pokoknya adalah menggerakkan karyawan dan segenap fasilitas-fasilitas yang ada pada kantor tersebut. 


\section{Pendidikan dan Pelatihan}

1. Pengertian Pendidikan Menurut Ahli

Dengan perkembangan zaman di dunia pendidikan yang terus berubah dengan signifikan sehingga banyak merubah pola pikir pendidik, dari pola pikir yang awam dan kaku menjadi lebih modern. Hal tersebut sangat berpengaruh dalam kemajuan pendidikan di Indonesia. Menyikapi hal tersebut pakar-pakar pendidikan mengkritisi dengan cara mengungkapkan dan teori pendidikan yang sebenarnya untuk mencapai tujuan pendidikan yang sesungguhnya.

Tujuan pendidikan adalah menciptakan seseorang yang berkualitas dan berkarakter sehingga memiliki pandangan yang luas kedepan untuk mencapai suatu cita- cita yang di harapkan dan mampu beradaptasi secara cepat dan tepat di dalam berbagai lingkungan. Karena pendidikan itu sendirimemotivasi diri kita untuk lebih baik dalam segala aspek kehidupan.Pendidikan bisa saja berawal dari sebelum bayi lahir seperti yang dilakukan oleh banyak orang dengan memainkan musik dan membaca kepada bayi dalam kandungan dengan harapan ia bisa mengajar bayi mereka sebelum kelahiran.

Bagi sebagian orang, pengalaman kehidupan sehari-hari lebih

berarti daripada pendidikan formal. Seperti kata Mark Twain, "Saya tidak pernah membiarkan sekolah mengganggu pendidikan saya."

Baiklah langsung saja kita paparkan beberapa pengertian pendidikan menurut beberapa sumber.

Pada dasarnya pengertian pendidikan ( UU SISDIKNAS No.20 tahun 2003 ) adalah usaha sadar dan terencana untuk mewujudkan suasana belajar dan proses pembelajaran agar peserta didik secara aktif mengembangkan potensi dirinya untuk memiliki kekuatan spiritual keagamaan, pengendalian diri, kepribadian, kecerdasan, akhlak mulia, serta keterampilan yang diperlukan dirinya dan masyarakat.

Menurut kamus Bahasa Indonesia Kata “pendidikan” berasal dari kata 'didik' dan mendapat imbuhan 'pe' dan akhiran 'an', maka kata ini mempunyai arti proses atau cara atau perbuatan mendidik. Secara bahasa definisi pendidikan adalah proses pengubahan sikap dan tata laku seseorang atau kelompok orang dalam usaha mendewasakan manusiamelalui upaya pengajaran dan pelatihan.

Menurut Ki Hajar Dewantara (Bapak Pendidikan Nasional Indonesia) menjelaskan tentang pengertian pendidikan yaitu: Pendidikan yaitu tuntutan di dalam hidup tumbuhnya 
anak-anak, adapun maksudnya, pendidikan yaitu menuntun segala kekuatan kodrat yang ada pada anak-anak itu, agar mereka sebagai manusia dan sebagai anggota masyarakat dapatlah mencapai keselamatan dan kebahagiaan setinggi-tingginya.

Pendidikan adalah usaha sadar untuk menyiapkan peserta didik melalui kegiatan bimbingan, pengajaran, dan atau latihan bagi peranannya di masa yang akan datang.

Menurut UU No. 20 tahun 2003

Pendidikan adalah usaha sadar dan terencana untuk mewujudkan suasana belajar dan proses pembelajaran agar peserta didik secara aktif mengembangkan potensi dirinya untuk memiliki kekuatan spiritual keagamaaan, pengendalian diri, kepribadian, kecerdasan, akhlak mulia, serta ketrampilan yang diperlukan dirinya, masyarakat, bangsa, dan Negara. Sedangkan pengertian pendidikan menurut $\mathrm{H}$. Horne

Pendidikan adalah proses yang terus menerus (abadi) dari penyesuaian yang lebih tinggi bagi makhluk manusia yang telah berkembang secara fisik dan mental, yang bebas dan sadar kepada tuhan, seperti termanifestasi dalam alam sekitar intelektual, emosional dan kemanusiaan dari manusia.

Dari beberapa pengertian pendidikan menurut ahli tersebut maka dapat disimpulkan bahwa "Pendidikan adalah Bimbingan atau pertolongan yang diberikan oleh orang dewasa kepada perkembangan anak untuk mencapai kedewasaannya dengan tujuan agar anak cukup cakap melaksanakan tugas hidupnya sendiri tidak dengan bantuan orang lain”.

Menurut M.J Langeveld

Pendidikan adalah merupakan upaya manusia dewasa membimbing manusia yang belum dewasa kepada kedewasaan. Pendidikan ialah usaha menolong anak untuk melaksanakan tugastugas hidupnya, agar bisa mandiri, akil-baliq, dan bertanggung jawab secara susila. Pendidikan adalah usaha mencapai penentuan diri, susila dan tanggung jawab. Menurut Prof.Dr.Langeveld

Pendewasaan diri, dengan ciri-cirinya yaitu : kematangan berpikir, kematangan emosional, memiliki harga diri, sikap dan tingkah laku yang dapat diteladani serta kemampuan pengevaluasian diri. Kecakapan atau sikap mandiri, yaitu dapat ditandai pada sedikitnya ketergantungan pada orang lain dan selalu berusaha mencari sesuatu tanpa melihat orang lain. 


\section{Menurut Driyarkara}

Pendidikan didefinisikan sebagai upaya memanusiakan manusia muda atau pengangkatan manusia muda ke taraf insani. (Driyarkara, Driyarkara Tentang Pendidikan, Yayasan Kanisius, Yogyakarta, 1950, hal.74)

\section{Menurut Stellavan Petten Henderson}

Pendidikan merupakan kombinasai dari pertumbuhan dan perkembangan insani dengan warisan sosial. Kohnstamm dan Gunning (1995) : Pendidikan adalah pembentukan hati nurani. Pendidikan adalah proses pembentukan diri dan penetuan diri secara etis, sesuai dengan hati nurani

\section{Menurut John Dewey (1978)}

Education is all one with growing it has no end beyond itself (pendidikan adalah segala sesuatu bersamaan dengan pertumbuhan pendidikan sendiri tidak punya tujuan akhir di balik dirinya)

\section{Menurut H.H Horne}

Dalam pengertian luas, pendidikan merupakan perangkat dengan mana kelompok sosial melanjutkan keberadaannya memperbaharui diri sendiri, dan mempertahankan idealidealnya. Carter V. Good Pendidikan adalah proses perkembangan kecakapan seseorang dalam bentuk sikap dan prilaku yang berlaku dalam masyarakatnya. Proses sosial dimana seseorang dipengaruhi oleh sesuatu lingkungan yang terpimpin (khususnya di sekolah) sehingga iya dapat mencapai kecakapan sosial dan mengembangkan kepribadiannya.

\section{Menurut Thedore Brameld}

Istilah pendidikan mengandung fungsi yang luas dari pemelihara dan perbaikan kehidupan suatu masyarakat, terutama membawa warga masyarakat yang baru mengenal tanggung jawab bersama di dalam masyarakat. Jadi pendidikan adalah suatu proses yang lebih luas daripada proses yang berlangsung di dalam sekolah saja. Pendidikan adalah suatu aktivitas sosial yang memungkinkan masyarakat tetap ada dan berkembang. Di dalam masyarakat yang kompleks, fungsi pendidikan ini mengalami spesialisasi dan melembaga dengan pendidikan formal yang senantiasa tetap berhubungan dengan proses pendidikan informal di luar sekolah).

\section{Pelatihan}

\section{Pengertian, Tujuan Pendidikan Dan Pelatihan Menurut Ahli}

Dilihat dari istilah pendidikan dan pelatihan maka istilah tersebut terdiri dari dua kata yaitu kata pendidikan dan kata pelatihan. Kata pendidikan dan kata pelatihan dalam 
beberapa kekepustakaan dijelaskan memiliki pengertian yang tidak sama atau dengan kata lain memiliki pengertian sendiri-sendiri. Demikian pula terdapat kepustakaan yang lainnya menyatakan bahwa pendidikan dan pelatihan adalah merupakan satu istilah atau dengan kata lain memiliki mengertian yang satu.

Untuk dapat memahami secara lebih jelasnya tentang perbedaan pengertian pendidikan dan pelatihan tersebut maka dalam uraian selanjutnya akan dicoba dijelaskan secara lebih lengkap dengan mengutip beberapa pendapat, seperti yang dikemukakan oleh Atmodiwirio (2002) yang menyatakan bahwa pendidikan adalah pembelajaran yang dipersiapkan untuk meningkatkan pelaksanaan pekerjaan pada masa yang akan datang atau meningkatkan seseorang untuk dapat menerima tanggungjawab dan atau tugas-tugas baru. Ada juga pendapat yang menyatakan pendidikan tersebut adalah kegiatan untuk memperbaiki kemampuan karyawan dengan cara meningkatkan pengetahuan dan pengertian teoritis baik pengetahuan umum maupun pengetahuan yang berkaitan dengan bisnis umumnya dan yang berkaitan dengan tugas dan tanggungjawabnya termasuk di dalamnya keterampilan di dalam mengambil keputusan (Gorda. 2006). Demikian pula dalam Undang-undang No. 20 tahun 2003 yang mengatur tentang Sistem Pendidikan Nasional memberikan pengertian pendidikan sebagai usaha sadar dan terencana untuk mewujudkan suasana belajar dan proses pembelajaran agar peserta didik secara aktif mengembangkan potensi dirinya untuk memiliki kekuatan sepiritual keagamaan, pengendalian diri, kepribadian, kecerdasan, akhlak mulia, serta keterampilan yang diperlukan dirinya, masyarakat, bangsa dan negara.

Dari beberapa pengertian pendidikan tersebut terkesan bahwa konsep pendidikan tidak hanya terbatas pengertiannya pada lingkup organisasi pekerjaan tetapi juga termasuk organisasi pendidikan. Pendidikan dianggap lebih luas lingkupnya dari pada pelatihan, karena pendidikan yang dimaksudkan mencakup pendidikan formal seperti pendidikan di sekolah, akademi maupun di perguruan tinggi. Bertitik tolak dari pengertian pendidikan sebagai lingkup organisasi pekerjaan juga terkesan ada kemungkinan dua makna yang terkandung dalam konsep pendidikan, yaitu (1) suatu pekerjaan tertentu harus diisi pada jangka waktu yang pasti, dan (2) suatu pekerjaan tertentu yang harus diisi dalam jangka waktu yang tidak pasti atau di masa yang akan datang. Pendidikan dianggap sebagai suatu alat perentang respon karyawan ketimbang pengurangan. Pendidikan menunjukkan suatu perluasan individu sehingga dia dapat dipersiapkan untuk menilai berbagai stituasi dan memilih respon yang paling tepat. 
Di sisi yang lain pelatihan diberikan pengertian sebagai suatu proses di mana orangorang mencapai kemampuan tertentu untuk membantu mencapai tujuan organisasi (Mathis dan Jackson. 2000). Pelatihan adalah suatu kegiatan untuk memperbaiki kemampuan karyawan dengan cara meningkatkan pengetahuan keterampilan di dalam melaksanakan tugas dan tanggungjawab (Gorda. 2004). Pelatihan kerja adalah keselu-ruhan kegiatan untuk memberi, memperoleh, meningkatkan, serta mengembangkan kompetensi kerja, produktivitas, disiplin, sikap dan etos kerja pada tingkat keterampilan dan keahlian tertentu sesuai dengan jenjang dan kualifikasi jabatan dan pekerjaan (Simamora. 2004).

Pelatihan terdiri dari serangkaian aktifitas yang dirancang untuk meningkatkan keahlian atau pengetahuan tertentu. Program pelatihan mengajarkan kepada para peserta bagaimana menunaikan aktivitas atau pekerjaan tertentu. Dalam pelatihan juga diciptakan lingkungan di mana para karyawaan dapat memperoleh atau mempelajari sikap, kemampuan keahlian, pengetahuan, dan perilaku yang spesifik yang berhubungan dengan pekerjaan. Pelatihan terfokus pada penyediaan keahlian khusus bagi para karyawan atau membantu para karyawan membenahi kerja mereka, oleh karena itu pelatihan pada umumnya dilaksanakan melalui pendidikan non formal kursus-kursus singkat, penataran, lokarkarya, dan on the job training. Dengan demikian ada atau terdapat kedekatan pengertian antara pendidikan dan pelatihan, yaitu sama-sama dalam rangka meningkatkan kemampuan dan keterampilan karyawan atau pegawai negeri.

Berangkat dari pengertian pendidikan dan pelatihan seperti yang sudah dijelaskan di atas maka kedekatan pengertian antara pendidikan dan pelatihan tersebut dalam peraturan pemerintah No.101 tahun 2000 tentang pendidikan dan pelatihan jabatan pegawai negeri sipil malah justru dijadikan satu atau disatukan menjadi pendidikan dan pelatihan yang sealanjutnya disebut dengan istilah Diklat. Demikian pula kemudian diklat tersebut diberikan pengertian sebagai proses penyelenggaraan belajar mengajar dalam rangka meningkatkan kemampuan pegawai negeri sipil. Kemudian ada juga pendapat yang menyatakan bahwa pendidikan dan pelatihan adalah suatu program kesempatan belajar yang direncanakan untuk menghasilkan anggota staf ... demi memperbaiki penampilan seseorang yang telah mendapatkan tugas menduduki sesuatu jabatan tertentu (Wahjosumidjo.1999). Jadi bertitik tolak dari beberapa pengertian tentang pendidikan dan pelatihan tersebut, tampaknya pelatihan harus meningkatkan pelaksanaan tugas dan pengembangan karier pegawai. Pendidikan dan pelatihan harus menjadi suatu program yang berkelanjutan atau paling tidak merupakan suatu bagian dari kehidupan dan upaya dalam 
mencapai tujuan organisasi yang perlu dilakukan secara berulang. Dalam pendidikan dan pelatihan seharusnya juga dipergunakan metodelogi dan system atau metode penyampaian yang baru yang bisa dilakukan dengan metode studi lapangan, diskusi, seminar konferensi, role playing, simulasi, studi kasus, dan sebagainya.

Sebagai bahan kajian maupun untuk memperluas wawasan tentang pengertian pendidikan dan pelatihan tersebut maka di bawah ini dikutipkan beberapa pengertian pendidikan dan pelatihan sebagai berikut:

\section{a. Leonard Nadler}

Pendidikan dan pelatihan adalah pengalaman pembelajaran yang disiapkan oleh organisasi untuk meningkatkan kinerja pegawai pada saat sekarang.

\section{Tujuan, Sasaran dan Manfaat Pendidikan dan Pelatihan}

Tujuan pendidikan dan pelatihan dalam beberapa buku kepustakaan dirumuskan dengan cara yang berbeda-beda. Atmodiwirio (2002) menyatakan bahwa tujuan pendi-dikan dan pelatihan pada umumnya adalah: (1) Meningkatkan kesetiaan dan ketaatan pegawai negeri sipil kepada Pancasila dan UUD 1945, Negara dan pemerintah Republik Indonesia, (2) Menanamkan kesaamaan pola pikir yang dinamis dan bernalar agar memiliki wawasan yang komprehensif untuk melaksanakan tugas umum pemerintah dan pembangunan, (3) Memantapkan semangat pengabdian yang berorientasi kepada pelayanan, pengayoman, dan pengembangan partisipasi masyarakat, (4) Meningkatkan pengetahuan, keahlian atau keterampilan serta pembentukkan sedini mungkin kepribadian pegawai negeri sipil, dan (5) Kesamaan visi dan dinamika pola pikir dalam melaksanakan tugas pemerintahan umum dan pembangunan demi terwujudnya pemerin-tahan yang baik. Kemudian Simamora (2004) menjelaskan bahwa tujuan pelatihan pada intinya adalah: (1) memperbaiki kinerja, karyawan-karyawan yang bekerja secara tidak memuaskan karena kekurangan keterampilan merupakan calon utama peserta pelatihan, (2) memutakhirkan keahlian para karyawan sejalan dengan kemajuan teknologi, melalui pelatihan, pelatih memastikan bahwa karyawan dapat mengaplikasikan teknologi baru secara efektif, (3) mengurangi waktu pembelajaran bagi karyawan baru agar kompeten dalam pekerjaan, (4) membantu memecahkan masalah operasional. Para manajer harus mencapai tujuan mereka dengan kelangkaan dan kelimpahan sumber daya, kelangkaan sumber daya financial dan sumberdaya teknologi manusia, (5) mempersiapkan karyawan untuk promosi. Salah satu cara untuk 
menarik, menahan, dan memotivasi karyawan adalah kosisten dengan kebijakan sumberdaya manusia untuk promosi dari dalam, pelatihan unsur kunci dari dalam system pengembangan karir, (6) mengorientasikan karyawan terhadap organisasi, dan (7) memenuhi kebutuhan partumbuhan pribadi (Simamora. 2004). Kemudian Dharma (2003) menjelaskan bahwa tujuan pelatihan adalah meningkatkan kemampuan karyawan melakukan pekerjaannya dengan lebih baik. Memperhatikan beberapa pendapat yang berkaitan dengan tujuan pendidikan dan pelatihan tersebut bahwa dapat dipahami bahwa sesungguhnya pendidikan dan pelatihan tersebut tidak hanya berkaitan dengan pengembangan sumberdaya manusia yang memegang jabatan sebagai pegawai negeri sipil, tetapi juga termasuk semua karyawan di luar pegawai negeri sipil, apakah karyawan di perusahan dan semua industri pada umumnya, dengan kata lain semua sumberdaya manusia perlu mendapat pendidikan dan pelatihan. Lebih dari itu apabila rumusan dari tujuan pendidikan dan pelatihan tersebut terkesan berbeda-beda juga disebabkan oleh dipengaruhi dan ada hubuhgannya dengan jenis-jenis pendidikan dan pelatihan yang dijadikan dasar atau sebagai titik pandang mengkajinya, karena di dalam membahas pendidikan dan pelatihan sebagai pengembangan sumberdaya manusia tersebut bisa dilihat dari metode, strategi, ataupun jenis-jenisnya cukup banyak. Dalam hubungan dengan metode pendidikan dan pelatihan Tovey yang dikutif oleh Irianto (2001) menjelaskan ada beberapa metode pelatihan, seperti:

1) Brainstorming adalah merupakan sutau metode pendidikan dan pelatihan yang digunakan untuk mengembangkan ide tentang sesuatu topik atau untuk membangun ide-ide yang sebelumnya telah digagaskan. Di dalamnya menggunakan suatu aturan utama yaitu semua partisipan harus secara kritis merespon semua ide yang diberikan dalam pelatihan dan tidak begitu saja menerima atau membenarkan.

2) Buzz group, sekelompok kecil peserta diberi topik tertentu untuk mendiskusikan secara intensif dan setiap kelompok harus membuat rekomendasi atau keputusan tentang topik atau masalah yang telah diberikan.

3) Case studies, menyajikan suatu masalah untuk dipecahkan oleh seluruh peserta. Biasanya disajikan dalam format tercetak, namun tidak selalu harus seperti demikian. Kadang-kadang bedasarkan suatu kondisi kehidupan nyata. Dirancang untuk selalu terakit dengan masalah dan isu yang berasosiasi dengan masalahmasalah keseharian. 
4) Computer managed learning, pembelajaran yang disajikan melalui perangkat computer dan dinilai oleh computer itu sendiri yang kemudian memberi umpan balik kepada mereka.

5) Critical incidents jenis studi kasus yang melihat kejadian atau fakta siatuasi kehidupan nyata secara kritis dimana pelatih atau peserta pernah mengalaminya.

Demikian pula disisi yang lain pelatihan memiliki manfaat yang sangat besar, yaitu;

1. Meningkatkan kuantitas dan kualitas produktivitas,

2. Mengurangi waktu belajar yang diperlukan karyawan untuk mencapai standar kinerja yang dapat diterima,

3. Membentuk sikap, loyalitas, dan kerjasama yang lebih menguntungkan,

4. Memenuhi kebutuhan perencanaan sumberdaya manusia,

5. Mengurangi frekuensi dan biaya kecelakaan kerja, dan

6. Membantu karyawan dalam meningkatan dan mengembangkan pribadi mereka (Simamora. 2004).

Berbeda dengan Atmodiwirio (2002) menyatakan bahwa pendidikan dan pelatihan tersebut sangat diperlukan oleh suatu organisasi, karena memiliki berbagai manfaat diantaranya adalah:

1. Bermanfaat untuk memenuhi kebutuhan organisasi, organisasi membutuhkan orang-orang yang mampu melaksanakan tugas yang telah ditetapkan sesuai dengan pengertian jabatan. Untuk dapat melaksanakan jabatan itu maka orang tersebut perlu memperoleh pengetahuan dan keterampilan tentang bagaimana melaksanakn tugas tersebut. Melalui pelatihan diharapkan kebutuhan dan kekeurangannya dapat dipenuhi, sehingga ia dapat melaksanakan tugasnya dengan cepat dan tepat,

2. Bermanfaat untuk memenuhi kebutuhan pribadi, kebutuhan peribadi merupakan bagian yang tidak terpisahkan dari organisasi. Kebutuhan pribadi melengkapi kebutuhan organisasi. Pengembangan pribadi yang diperoleh melalui pengembangan jabatan akan memperkaya dirinya. Itulah yang disebut pengembangan karir,

3. Bermanfaat untuk memenuhi kebutuhan invertasi sumberdaya manusia, diklat tak ubahnya sebagai pendidikan formal membutuhkan pengadaan biaya yang tidak sedikit. Memilih diklat sebagai suatu investasi sumberdaya manusia walaupun masih diragukan hasilnya tetap banyak perusahaan yang menugaskan tenaga-tenaga intinya untuk mengikuti diklat di dalam dan di luar negeri, dan

4. Bermanfaat bagi setiap penjabat/jenjang keangkatan. Hal ini dapat dilihat pada diklat PNS dimulai dari diklat bagi esolan I, II, III, dan IV. 
5. Jenis dan Jenjang, Strategi Pendidikan dan Pelatihan

6. Ada beberapa jenis pendidikan dan pelatihan yang dapat diselenggarakan oleh suatu organisasi, diantaranya adalah pendidikan dan pelatihan keahlian, pendidikan dan pelatihan ulang, pendidikan dan pelatihan fungsional silang, pendidikan dan pelatihan tim, dan pendidikan dan pelatihan kreatifitas. Secara lebih rinci untuk dapat memahami jenis pendidikan pelatihan tersebut dapat dilihat dalam pembahasan yang dilakukan oleh Simamora (2004).

Pelatihan keahlian merupakan pelatihan yang sering dijumpai dalam suatu organisasi. Program pendidikan dan pelatihan relatif sederhana, kebutuhan diidentifikasi melalui penilaian yang jeli. Kriteria penilaian efektifitas pelatihan berdasarkan pada sasaran yang diidentifikasi dalam tahap penilaian.

Pelatihan ulang adalah subsistem dari pelatihan keahlian. Pelatihan ulang berupaya memberikan kepada para karyawan keahlian yang mereka butuhkan untuk menghadapi tuntutan kerja yang berubah-ubah. Umpamanya karyawan yang selama ini memakai mesin produksi yang terkomputerisasi.

Pendidikan pelatihan lintas fungsional. Pada dasarnya organisasi telah mengembangkan fungsi kerja yang telah tersepesialisasi dan deskripsi pekerjaaan yang rinci. Walaupun demikian dewasa ini organisasi lebih menekankan pada multi keahlian ketimbang spesialisasi. Pelatihan karyawan dalam berbagai fungsi menjadi semakin ppopuler. Pendidikan dan pelatihan model ini melibatkan pelatihan karyawan untuk melakukan aktivitas kerja dalam bidang lainnya selain dari pekerjaan yang ditugaskan. Terdapat banyak pendekatan untuk pelatihan lintas fungsional, seperti: rotasi pekerjaan dapat diupergunakan untuk memberikan suatu persepektif yang lebih luas kepada manajer dalam satu bidang fungsional, departemen dapat saling bertukar karyawan untuk periode waktu tertentu sehingga setiap karyawan mengembangkan suatu pemahaman mengenai aktivitas departemen lainnya, kemudian pelatihan adalah kolega kerja, karyawankaryawan yang berprestasi bertindak sebagai internal on-the-job trainers, dapat menolong para karyawan mengembangkan keahlian aktivitas kerja lainnya.

Pelatihan tim. Dewasa ini ada gejala perlunya akan adanya peningkatan kinerja terhadap tim-tim yang ada dalam suatu organisasi. Dalam suatu organisasi pada saat ini cendrung terdapat berbagai tim, seperti tim riset, dan tim-tim yang bersifat temporer. Tim adalah sekelompok individu yang bekerjasama demi tujuan bersama. Tujuan bersama itulah sebenarnya menentukan sebuah tim, dan seandainya seorang anggota mempunyai tujuan-tujuan yang bertentangan, maka efisiensi dan efektivitas sdari suatu organisasi akan dapat terganggu. 
Pendidikan dan pelatihan kreativitas. Pendidikan dan pelatihan berlandaskan pada asumsi bahwa kreativitas dapat dipelajari. Ada beberapa cara untuk mengajarkan kreativitas, yang semuanya berusaha mengajar dan membantu orang-orang dalam memecahkan masalah dalam kiat baru. Salah satu ancangan yang lazim diterapkan adalah brainstorming di mana para parisipan diberikan peluang untuk mengeluarkan gagasan sebebas mungkin. Setelah gagasan dianggap cukup banyak, para partisipan diminta memebrikan penilaian rasional dari segi biaya dan kelaikan. Kreativitas biasanya dianggap mempunyai dua tahap yaitu imajinatif dan praktis. Teknik brainstorming yang diikuti oleh pertimbangan rasional dari opsi yang dihasilkannya memenuhi kedua tahap tersebut.

\section{PEMBAHASAN DAN HASIL}

\section{Kementerian Riset, Teknologi, dan Pendidikan Tinggi Republik Indonesia}

Kementerian Riset, Teknologi, dan Pendidikan Tinggi Republik Indonesia adalah kementerian dalam Pemerintah Indonesia yang menyelenggarakan urusan di bidang riset, teknologi, dan pendidikan tinggi. Kementerian Riset, Teknologi, dan Pendidikan Tinggi berada di bawah dan bertanggung jawab kepada Presiden. Kemenristekdikti dipimpin oleh seorang Menteri Riset, Teknologi dan Pendidikan Tinggi (Menristekdikti) yang sejak tanggal 27 Oktober 2014 dijabat oleh Muhammad Nasir.

\section{Sejarah Perusahaan}

Berdiri sejak tahun 1962 dengan nama Kementerian Urusan Riset Nasional Republik Indonesia, kemudian pada tahun 1973 berubah nama menjadi Menteri Negara Riset. Periode tahun 1986-2001 menjadi Menteri Negara Riset dan Teknologi, dan tahun 2002 sesuai Surat

Edaran Menteri Negara Pendayagunaan Aparatur Negara perihal Penamaan Instansi Pemerintah, Kantor Menteri Negara disebut dengan Kementerian Riset dan Teknologi. Pada tahun 2005, berdasarkan Peraturan Presiden Nomor 9 Tahun 2005 institusi ini disebut Kementerian Negara Riset dan Teknologi (KNRT) atau dengan sebutan Kementerian Negara Ristek sebelum kembali berganti nomenklatur sesuai Peraturan Presiden Nomor 47 Tahun 2009 menjadi Kementerian Riset dan Teknologi.

Pada tahun 2014 pada masa kepemimpinan Presiden Jokowi, nomenklatur Kementerian Riset dan Teknologi kembali berubah menjadi Kementerian Riset, Teknologi, dan 
Pendidikan Tinggi. Perubahan ini merupakan konsekuensi dari penggabungan urusan pendidikan tinggi ke kementerian ini yang sebelumnya berada di bawah Kementerian Pendidikan dan Kebudayaan.

\section{Tugas dan fungsi}

Kementerian Riset, Teknologi, dan Pendidikan Tinggi mempunyai tugas menyelenggarakan urusan pemerintahan di bidang riset, teknologi, dan pendidikan tinggi untuk membantu Presiden dalam menyelenggarakan pemerintahan negara.Dalam melaksanakan tugas, Kementerian Riset, Teknologi, dan Pendidikan Tinggi menyelenggarakan fungsi:

a. Perumusan, penetapan, dan pelaksanaan kebijakan di bidang standar kualitas sistem pembelajaran, lembaga pendidikan tinggi, sumber daya manusia serta sarana dan prasarana pendidikan tinggi, dan keterjangkauan layanan pendidikan tinggi;

b. Perumusan dan penetapan kebijakan di bidang standar kualitas lembaga penelitian, sumber daya manusia, sarana dan prasarana riset dan teknologi, penguatan inovasi dan riset serta pengembangan teknologi, penguasaan alih teknologi, penguatan kemampuan audit teknologi, perlindungan Hak Kekayaan Intelektual, percepatan penguasaan, pemanfaatan, dan pemajuan riset dan teknologi;

c. Koordinasi dan sinkronisasi pelaksanaan kebijakan di bidang kelembagaan, sumber daya, penguatan riset dan pengembangan, serta penguatan inovasi ilmu pengetahuan dan teknologi;

d. Pemberian izin tertulis kegiatan penelitian dan pengembangan oleh perguruan tinggi asing, lembaga penelitian dan pengembangan asing, badan usaha asing, dan orang asing di wilayah Negara Kesatuan Republik Indonesia;

e. Pemberian izin tertulis kegiatan penelitian dan pengembangan terapan ilmu pengetahuan dan teknologi yang berisiko tinggi dan berbahaya sesuai dengan ketentuan peraturan perundang-undangan;

f. Koordinasi pelaksanaan tugas, pembinaan, dan pemberian dukungan administrasi kepada seluruh unsur organisasi di lingkungan Kementerian Riset, Teknologi, dan Pendidikan Tinggi;

g. Pengelolaan barang milik/kekayaan negara yang menjadi tanggung jawab Kementerian Riset, Teknologi, dan Pendidikan Tinggi;

h. Pengawasan atas pelaksanaan tugas di lingkungan Kementerian Riset, Teknologi, dan Pendidikan Tinggi; dan 
i. Pelaksanaan dukungan substantif kepada seluruh unsur organisasi di lingkungan Kementerian Riset, Teknologi, dan Pendidikan Tinggi.

\section{Koordinasi}

Berdasarkan Peraturan Presiden Nomor 64 Tahun 2005 tentang Perubahan Keenam atas Keputusan Presiden No. 103 Tahun 2001 tentang Kedudukan, Tugas, Fungsi, Kewenangan, Susunan Organisasi, Dan Tata Kerja LembagaPemerintah Non Kementerian, Menteri Negara Riset, Teknologi dan Pendidikan Tinggi mengkoordinasikan LPNK sebagai berikut:

a. Lembaga Ilmu Pengetahuan Indonesia (LIPI)

b. Lembaga Penerbangan dan Antariksa Nasional (LAPAN)

c. Badan Pengkajian dan Penerapan Teknologi (BPPT)

d. Badan Tenaga Nuklir Nasional (BATAN)

e. Badan Pengawas Tenaga Nuklir (BAPETEN)

f. Badan Informasi Geospasial (BIG)

g. Badan Standardisasi Nasional (BSN)

Kementerian Riset, dan Teknologi juga mengkoordinasikan, dan mengelola lembagalembaga sebagai berikut :

a. Pusat Penelitian Ilmu Pengetahuan dan Teknologi (PUSPIPTEK)

b. Lembaga Biologi Molekuler Eijkman (Lembaga Eijkman) (LBME)

c. Pusat Peragaan Ilmu Pengetahuan dan Teknologi (PUSPA IPTEK)

d. Agro Techno Park (ATP) Palembang

e. Business Technology Center (BTC)

\section{Visi dan Misi}

Dengan pertimbangan menjalankan mandat Undang-Undang Dasar 1945, UndangUndang Nomor 18 Tahun 2012 tentang Sistem Nasional Penelitian, Pengembangan dan Penerapan Iptek, dan Undang-Undang Nomor 12 Tahun 2012 tentang Pendidikan Tinggi serta dengan mempertimbangkan kondisi umum dan aspirasi masyarakat, kerangka kerja logis yang dibangun untuk menopang daya saing nasional, mengoptimalkan potensi yang dimiliki oleh Kemenristekdikti, maka disusun Visi, Misi, Tujuan dan Sasaran Strategis sebagai berikut. 


\section{VISI}

"Terwujudnya pendidikan tinggi yang bermutu serta kemampuan iptek dan inovasi untuk mendukung daya saing bangsa"

\section{MISI}

Sebagai upaya untuk mewujudkan visi tersebut di atas, maka misi Kemenristekdikti adalah :

1. Meningkatkan akses, relevansi, dan mutu pendidikan tinggi untuk menghasilkan SDM yang berkualitas; dan

2. Meningkatkan kemampuan Iptek dan inovasi untuk menghasilkan nilai tambah produk inovasi.

\section{TUJUAN STRATEGI}

Dalam rangka mencapai visi dan misi Kemenristekdikti seperti yang dikemukakan di atas, maka visi dan misi tersebut dirumuskan ke dalam bentuk yang lebih terarah dan operasional berupa perumusan tujuan strategis (strategic goals). Dalam rangka memecahkan permasalahan yang dihadapi seperti yang dijelaskan pada bagian sebelumnya dalam rangka mewujudkan visi dan melaksanakan misi Kemenristekdikti, maka tujuan strategis yang harus dicapai adalah :

"Meningkatnya relevansi, kuantitas dan kualitas sumber daya manusia berpendidikan tinggi, serta kemampuan Iptek dan inovasi untuk keunggulan daya saing bangsa"

Untuk melihat secara lebih konkrit ketercapaian tujuan strategis tersebut perlu ditetapkan ukuran indikator tujuan tersebut secara kuantitatif. Dalam rancangan lima tahun ke depan, indikator kinerja tujuan strategis diukur dengan indeks pendidikan tinggi pada tahun 2019 ditargetkan berada pada peringkat 56 besar dunia dengan nilai 5,0 dan indeks inovasi Indonesia pada tahun 2019 yang ditargetkan berada pada peringkat 26 besar dunia dengan nilai 4,4 .

\section{SASARAN STRATEGI}

Tujuan strategis tersebut kemudian dijabarkan dalam 5 (lima) sasaran strategis sesuai dengan permasalahan-permasalahan yang harus diselesaikan dalam kurun waktu 2015-2019. Sasaran strategis tersebut adalah :

1. Meningkatnya kualitas pembelajaran dan kemahasiswaan pendidikan tinggi;

2. Meningkatnya kualitas kelembagaan Iptek dan pendidikan tinggi; 
3. Meningkatnya relevansi, kualitas, dan kuantitas sumber daya Iptek dan pendidikan tinggi;

4. Meningkatnya relevansi dan produktivitas riset dan pengembangan; dan

5. Menguatnya kapasitas inovasi.

\section{Pembahasan dan Hasil}

\section{Tempat dan Waktu Pelaksanaan Praktek Lapangan Kerja}

Tempat pelaksanaan Praktik Kerja Lapangan di bagian Tata Usaha Kantor Pusat Pendidikan dan Pelatihan Kementerian Riset, Teknologi dan Pendidikan Tinggi yang beralamat di Jalan MH. Thamrin nomor.8, Jakarta Pusat, yaitu mulai tanggal 1 Maret sampai dengan 30 April 2016.

2. Menangani surat keluar, surat masuk dan melakukan pengarsipan merupakan kegiatan rutin yang dilakukan di bagian Tata Usaha Kantor Pusat Pendidikan dan Pelatihan Kementerian Riset Teknologi dan Pendidikan Tinggi. Kegiatan penanganan surat dan pengarsipan ini sangat penting untuk dilakukan karena merupakan salah satu sarana komunikasi yang berperan penting bagi kelancaran suatu perusahaan/organisasi.

Pada saat melakukan Praktik Kerja Lapangan di bagian Tata Usaha Kantor Pusat Pendidikan dan Pelatihan Kementerian Riset, Teknologi dan Pendidikan Tinggi, penulis mendapatkan tugas:
a. Menerima surat masuk
b. Mencatat surat masuk di buku agenda surat masuk
c. Mencatat surat keluar di buku agenda surat keluar
d. Membuat disposisi
e. Menggandakan surat
f. Melakukan scaning surat untuk dikirim melalui email

Alur Surat Masuk dan Surat Keluar di Bagian Tata Usaha Kantor Pusat Pendidikan dan Pelatihan Kementerian Riset, Teknologi dan Pendidikan Tinggi Alur Surat Masuk: 


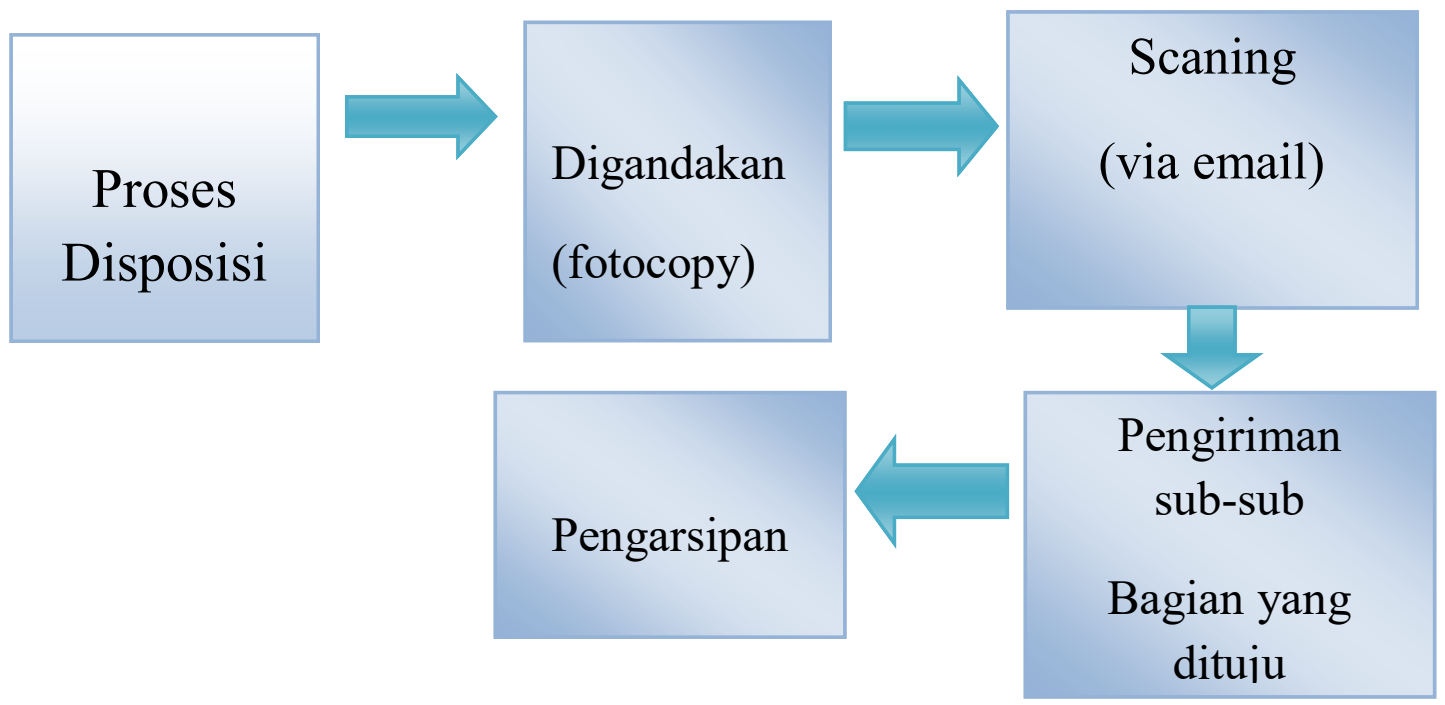

\section{KESIMPULAN DAN SARAN}

\section{Kesimpulan}

Berdasarkan data-data yang telah penulis miliki dari pembahasan yang telahdiuraikan pada bab IV, penulis dapat menarik kesimpulan sebagai berikut :

1. Kebijaksanaan yang dibuat untuk memperbaiki cara kerja pegawai sebagai suatu rutinitas. Kebijaksanaan yang dibuat antara lain tentang penataan arsip dan pengagendaan surat. Surat yang diarsip yaitu surat keluar yang minta nomor sura tdan surat masuk untuk keperluan dinas atas perintah atasan disertai lembar disposisi, sehingga kebijaksanaan tersebut dapat berjalan dengan baik karena kebijaksanaan yang dibuat berdasarkan pada situasi dan kondisi sekarang dan melibatkan pihak-pihak yang terkait.

2. Pelaksanaan sistem kearsipan yang dilaksankan pada Bagian Tata Usaha Kementerian Riset, Teknologi dan Pendidikan Tinggi dari penerimaan surat masuk dan surat keluar dengan melakukan pencatatan yaitu untuk surat masuk dicatat dahulu dalam buku surat masuk sedangkan untuk surat keluar juga dicatat dalam buku agenda surat keluar.

3. Penempatan surat pada ordner, ordnernya tidak memiliki kejelasan pada penulisan isi didalamnya surat dari nomor berapa sampai berapa, tidak ada kejelasan tulisan isi surat di dalamnya dari bulan dan tahun berapa sampai bulan dan tahun keberapa/selanjutnya.

4. Dalam pengelolaan sistem arsip di bagian Tata Usaha Kementerian Riset, Teknologi dan Pendidikan tinggi adalah sistem sistematik.

5. Peminjaman arsip di Kemenristekdikti yang sering dilakukan tanpa ada konfirmasi atau pemberitahuan mengenai peminjaman arsip tersebut, karena saat arsip dipinjam sering terjadi miscomunication antara bagian sub satu dengan bagian sub yang lainnya. 
6. Untuk pemeliharaan fisik arsip dengan pemberian kapur barus atau obat anti serangga dan untuk pemeliharaan lingkungan dengan membersihkan setiap pagi oleh petugas kebersihan atau cleaning service. Untuk penyusutan dan pemusnahan jarang dilakukan.

7. Fasilitas kearsipan yang terdapat pada kantor Kemenristekdikti sudah baik karena sebagian besar peralatan sudah ada dengan fasilitas-fasilitas tersebut sudah dapat memenuhi kebutuhan dalam kegiatan kearsipan.

8. Tata ruang kearsipan pada kantor Kemenristekdikti belum mempunyai ruangan khusus yang digunakan sebagai tempat penyimpanan arsip, ruangan arsip masih menjadi satu dengan ruang kerja.

9. Pegawai kearsipan pada kantor Kemendistekdikti adalah seluruh pegawai kantor Kemenristekdikti tersebut dan telah dilakukan pembagian jabatan yang jelas, namun kurang adanya pembagian dalam penempatan pengelolaan keaarsipan pada kantor Kemenristekdikti.

Berdasarkan kesimpulan-kesimpulan diatas, maka agar pelaksanaan sistem kearsipan pada bagian Tata Usaha Kemenristekdikti perlu adanya perbaikan lebih lanjut dalam penataan pengelolaan penempatannya dan butuh beberapa penyempurnan

\section{Saran}

Sadar akan pentingnya pengelolaan surat dan penanganan arsip yang baik dan benar, penulis menambahkan saran untuk kemajuan pada bagian Tata Usaha Kantor Pusat Pendidikan dan Pelatihan Kementerian Riset, Teknologi dan Pendidikan Tinggi yaitu, perlu adanya penambahan pegawai dan pembagian tugas pada karyawan, agar penanganan surat dan pengelolaan arsip hanya ditanganin satu orang pegawai saja. Pengelolaan surat masuk lebih baik lagi menggunakan sistim karsipan baru yaitu dengan sistim kartu kendali agar tidak bergantung pada buku agenda sehingga penanganan surat dan pengelolaan arsip dapat berjalan dengan baik dan lebih efektif.

Pegawai pada bagian Tata Usaha Kantor Pusat Pendidkan dan Pelatihan Kementerian Riset, Teknologi dan Pendidikan Tinggi juga harus lebih teliti dan cekatan dalam menangani surat dan pengelolaan arsip, agar saat surat yang bersifat segera dibutuhkan dapat langsung diproses dan tidak akan memakan waktu yang cukup lama untuk menemukannya kembali. 


\section{DAFTAR PUSTAKA}

Binner Sitompul, SH. M.Hum, Kepala Pusat Pendidikan dan Pelatihan Kearsipan. Pengantar Kearsipan. Bogor, Desember 2015

Hendy Haryadi. Administrasi Perkantoran. Jakarta, Januari 2009

Dra. Suparjati, dkk. Tata Usaha dan Kearsipan.

www.landasanteori.com

www.7topranking.com 